\title{
DIRC3/HSPBAP1 Fusion Gene
}

National Cancer Institute

\section{Source}

National Cancer Institute. DIRC3/HSPBAP1 Fusion Gene. NCI Thesaurus. Code C99830.

A fusion gene that results from a chromosomal translocation $\mathrm{t}(2 ; 3)(\mathrm{q} 35 ; \mathrm{q} 21)$ which fuses the first 2 exons of the DIRC3 gene with the second coding exon of the HSPBAP1 gene. This rearrang ement is associated with familial renal cell carcinoma. 